\title{
Sistem Pendukung Keputusan Dalam Menentukan Tingkat Kepuasan Pelanggan Terhadap Pelayanan di Toko Indomaret Menggunakan Metode Fuzzy Associative Memory (FAM)
}

\author{
*Marsono, Ahmad Fitri Boy, Darjat Saripurna \\ Program Studi Sistem Informasi, STMIK Triguna Dharma \\ Jl. A.H Nasution No.73 Medan, Indonesia, 20142 \\ E-mail: marsonotgdok@gmail.com
}

\begin{abstract}
Abstrak
kepuasan pelanggan sangat krusial bagi kalangan bisnis, pemerintah, dan juga konsumen. Dalam dunia Usaha, tingkat kepuasan pelanggan dipandang sangat pital. Karena tingkat kepuasan pelanggan berpotensi pada meningkatnya pertumbuhan penjualan jangka panjang dan jangka pendek, serta pangsa pasar sebagai hasil pembelian ulang. Sedangkan, kualitas layanan adalah pendorong utama kesetiaan konsumen di mana kesetiaan tersebut terkait dengan perilaku konsumen. Ada beberapa kriteria dalam menentukan tingkat kepuasan pelanggan terhadap pelayanan yaitu dapat dilihat dari bukti langsung (fisik tampilan toko ataupun karyawan), kehandalan dan ketanggapan. Untuk itu dikembangkan sebuah Sistem Pendukung Keputusan yang di gunakan untuk menentukan tingkat kepuasan pelanggan terhadap pelayanan. Sistem ini juga merupakan suatu sistem informasi berbasis komputer yang menghasilkan berbagai alternatif keputusan yang membantu manajemen dalam menangani berbagai permasalahan yang terstruktur ataupun tidak terstruktur dengan menggunakan data atau model. Sistem ini biasanya dibangun untuk mendukung solusi atas suatu masalah atau untuk mengevaluasi suatu peluang.

Untuk meningkatkan ketelitian dalam menentukan kepuasan pelanggan terhadap pelayanan di toko indomaret dibutuhkan system yang baik. Sistem yang dimaksud adalah sistem Pendukung Keputusan dengan menggunakan metode Fuzzy Associative Memory (FAM)..
\end{abstract}

Kata Kunci: Sistem Pendukung Keputusan, Fuzzy Associative Memory, Tingkat Kepuasan

\begin{abstract}
customer satisfaction is crucial for businesses, governments, and consumers alike. In the business world, the level of customer satisfaction is considered very pital. Because the level of customer satisfaction has the potential to increase long-term and short-term sales growth, and market share as a result of repurchases. Meanwhile, service quality is the main driver of consumer loyalty where loyalty is related to consumer behavior. There are several criteria in determining the level of customer satisfaction with service that can be seen from direct evidence (physical appearance of the store or employee), reliability and responsiveness.For this reason, a Decision Support System was developed which is used to determine the level of customer satisfaction with the service. This system is also a computer-based information system that produces various alternative decisions that help management in dealing with various structured or unstructured problems using data or models. This system is usually built to support the
\end{abstract}


solution of a problem or to evaluate an opportunity.To improve accuracy in determining customer satisfaction with services in Indomaret stores, a good system is needed. The system in question is a Decision Support system using the Fuzzy Associative Memory (FAM) method

Keywords: Decision Support System, Fuzzy Associative Memory, Level of Satisfaction

\section{PENDAHULUAN}

Indomaret merupakan jaringan minimarket yang menyediakan kebutuhan pokok dan kebutuhan sehari-hari dan merupakan perusahaan retail terbesar di Indonesia. Dalam menjalankan usaha, seorang pemilik harus dapat menentukan strategi yang tepat untuk menciptakan kepuasan pelanggan, sehingga dapat meningkatkan sales pada usahanya. Untuk menciptakan kepuasan pelanggan tentunya tidak mudah, pemilik usaha harus dapat memberikan pelayanan yang berkualitas, baik secara langsung maupun tidak langsung kepada konsumen. Pelayanan yang baik tentunya dapat menjadi nilai lebih dari konsumen pada usaha yang dijalankan, sehingga dapat menyaingi kompetitor.

\section{METODE PENELITIAN}

1. Sistem Pendukung Keputusan

Sistem Pendukung Keputusan (Decision Support System) adalah sistem informasi interaktif yang menberikan informasi, pemodelan, dan pemanipulasian data. Sistem ini digunakan untuk membantu proses pengambilan keputusan dalam kondisi yang semiterstruktur dan yang tidak terstruktur, dimana tak seorang pun tahu pasti bagaimana keputusan seharusnya dibuat (Kusrini, 2017:15).

Sistem pendukung keputusan adalah sebua sistem informasi yang di rancang dna di bangun berbasiskan komputer yang dapat menghasilkan berbagai alternatif keputusan yang membantu manajemen dalam menangani berbagai permasalahan yang terstruktur ataupun tidak terstruktur dengan menggunakan data atau model. Sistem pendukung keputusan secara khusus dibangun untuk mencari solusi atas permasalahan yang ada atau untuk mengevaluasi suatu peluang atau kesempatan yang memungkinkan.Sistem tersebut didukung oleh sebuah sistem informasi berbasis komputer dapat membantu seseorang meningkatkan kinerjanya dalam pengambilan keputusan. Sistem pengambilan keputusan mendayagunakan sumber daya dari individu-individu dengan kemampuan komputer untuk meningkatkan kualitas keputusan. Oleh sebab itu sistem pendukung keputusan yang berbasis komputer ini dapat digunakan untuk manajemen pengambilan keputusan yang berhubungan dengan masalah-masalah yang semi terstruktur.

\section{Pelanggan}

Menurut Tjiptono (2012:55) "kepuasan pelanggan merupakan konsep sentral dalam wacana bisnis dan manajemen. Konsekuensi kepuasan pelanggan sangat krusial bagi kalangan bisnis, pemerintah, dan juga konsumen. Pada dunia usaha, kepuasan pelanggan dipandang sebagai salah satu unsuryang sangat penting. Peningkatan kepuasan pelanggan tersebut membawa dampak positif untuk laju pertumbuhan pasar jangka panjang dan jangka pendek, serta pangsa pasar sebagai hasil pembelian ulang". Fullerton, dalam Utami (2012:297) "kualitas layanan adalah pendorong utama kesetiaan konsumen di mana kesetiaan tersebut terkait dengan perilaku konsumen".

3. Fuzzy Associative Memory

Fuzzy Associative Memory (FAM) mengandung arti suatu model yang dilatih menggunakan jaringan syaraf, namun struktur jaringannya diinterpretasikan dengan 
sekelompok aturan-aturan fuzzy menurut Kasabov, 2002 (dalam Kusumadewi, 2010:297). Model arsitektur dari sistem FAM dapat dilihat seperti pada gambar berikut :

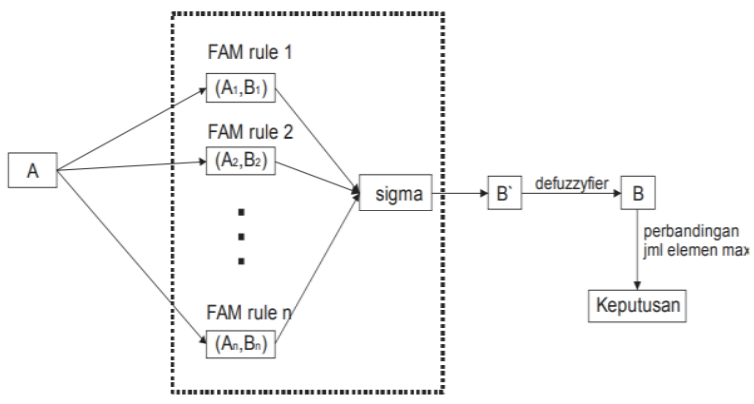

Gambar 1 Arsitektur FAM

Algoritma FAM adalah:

- Pembentukan fungsi keanggotaan

- Pembentukan matriks A dan B

- Pembentukan sistem FAM

- Melakuan perhitungan

III. ANALISIS DAN HASIL

1. Pembentukan Fungsi Keanggotaan

Dalam pembentukan fungsi keanggotaan terlebih dahulu ditentukan apa yang menjadi variabel input dari fungsi keanggotaan tersebut, dalam penelitian ini ditentukan beberapa variabel input untuk menghasilkan variabel output yaitu penilaian kepuasan pelanggan Ukuran kepuasan pelanggan dapat diukur dari kriteria berikut :

a. Bukti langsung (tangibles) adalah mencakup penampilan fisik, peralatan, personal dan media komunikasi. Indikator variabel ini adalah:

- Bangunan toko terlihat bersih

- Penataan dan pengaturan ruangan nyaman.

- Penampilan personil bersih dan rapi.

b. Kehandalan (realibility) adalah kemampuan untuk memberikan pelayanan dengan segera untuk memberikan kepuasan kepada pelanggan atau konsumen. Indikator variabel ini:

- Pelayanan yang ramah kepada konsumen

- Karyawan dapat diandalkan dan dipercaya.

- Karyawan dapat memberi informasi barang yang tepat.

c. Ketanggapan (responsiveness) adalah kemampuan untuk membantu pelanggan atau konsumen untuk memberikan pelayanan yang cepat dan tanggap. Indikator variabel ini adalah:

- Pelayanan yang diberikan cepat

- Konsumen tidak lama mengantri di kasiran.

- Karyawan berusaha menggapai keinginan konsumen.

J-SISKO TECH Vol. 3, No. 1, $2020: 78-85$ 
Tabel 3.1 Pemberian Skor Angka Variabel Bukti Langsung

Tabel 3.1 Pemberian Skor Angka Variabel Bukti Langsung

\begin{tabular}{|c|c|c|}
\hline No & Bukti langsung (tangibles) & Interval Skor Angka \\
\hline 1. & Tidak Baik & $0-40$ \\
\hline 2. & Cukup & 41.60 \\
\hline 3. & Baik & 61.80 \\
\hline
\end{tabular}

Tabel 3.2 Pemberian Skor Angka Variabel Kehandalan

\begin{tabular}{|c|c|c|}
\hline No & Kehandalan (reliability) & Interval Skor Angka \\
\hline 1. & Tidak Baik & $0-40$ \\
\hline 2. & Cukup & $41-60$ \\
\hline 3. & Baik & $61-80$ \\
\hline
\end{tabular}

Tabel 3.3 Pemberian Skor Angka Variabel Ketanggapan

\begin{tabular}{|c|c|c|}
\hline No & Ketanggapan (responsiveness) & Interval Skor Angka \\
\hline 1. & Tidak Baik & $0-40$ \\
\hline 2. & Cukup & $41-60$ \\
\hline 3. & Baik & $61-80$ \\
\hline
\end{tabular}

2. Pembentukan Matrisk A dan B

Setelah fungsi keanggotaan ditentukan, maka akan diperoleh derajat keanggotaan setiap data pada setiap himpunan dalam variabel bukti langsung, kehandalan, dan ketanggapan.

Variabel bukti langsung terdiri atas 3 himpunan, yang berarti bahwa:

$\mu[a]=\{\mu K U R A N G[p], \mu C U K U P[p], \mu B A G U S[p]\}$

Variabel kehandalan terdiri atas 3 himpunan, yang berarti bahwa:

$\mu[b]=\{\mu K U R A N G[p], \mu C U K U P[p], \mu B A G U S[p]\}$

Variabel ketanggapan terdiri atas 3 himpunan, yang berarti bahwa:

$\mu[c]=\{\mu K U R A N G[p], \mu C U K U P[p], \mu B A G U S[p]\}$

Satu FAM yang merupakan suatu pasangan himpunan (A, B) akan memetakan vektor input $A$ ke vektor input B. Mengingat variabel input yang dimiliki ada 3 yaitu bukti langsung (tangibles), kehandalan (reliability), dan ketanggapan (responsiveness), maka input vektor $A$ akan berisi 9 elemen, yaitu:

$A=(\alpha 1, \alpha 2, \alpha 3, \alpha 4, \alpha 5, \alpha 6, \alpha 7, \alpha 8, \alpha 9)$.

3. Pembentukan Sistem FAM

Sistem FAM terdiri atas 27 aturan (superimposing FAM rules). Pada setiap aturan akan memuat 27 pasangan ( $\mathrm{Ak}, \mathrm{Bk}$ ) dengan $\mathrm{k}=\mathrm{I}, 2, \ldots, 27$. Vektor input Ak berisi derajat keanggotaan ketanggapan produk ke-k pada himpunan KURANG, CUKUP, BAGUS, bukti langsung ke-k pada himpunan KURANG, CUKUP, BAGUS; dan derajat keanggotaan kehandalan ke-k pada himpunan KURANG, CUKUP, BAGUS. Selanjutnya didapat 27 matriks FAM (M1, M2, M3,..,M27) masing-masing berukuran 9x27 yang dibentuk dengan pengkodean korelasi minimum arsitektur sistem FAM seperti terlihat pada gambar berikut : 


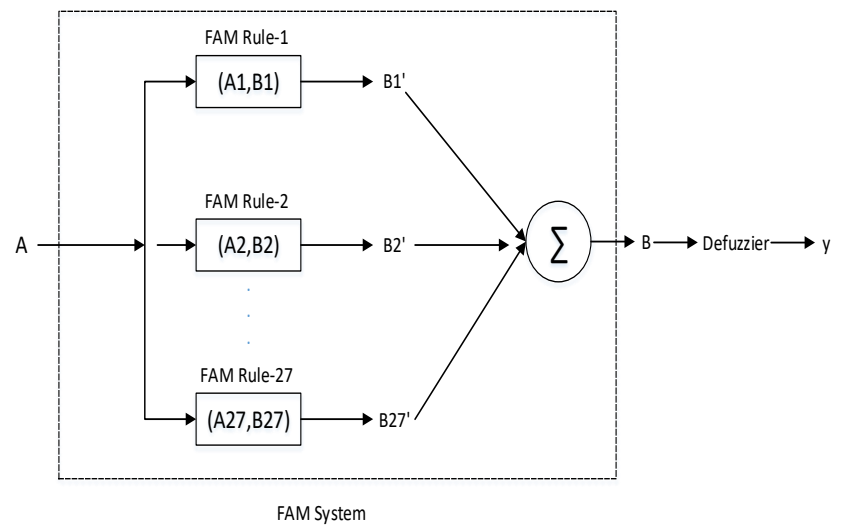

4. Pengujian

Gambar 2 Sistem FAM dengan 27 Aturan

Pengujian dilakukan pada data yang ikut dalam aturan dan data bebas yang tidak ikut dalam aturan. Pengujian dilakukan dengan mengambil nilai setiap bobot $w k=1(k=1,2, \ldots$, 27) dengan metode defuzzy winner take all. Matriks Bk' tidak digunakan baik komposisi maks-min maupun komposisi maks-produk, namun digunakan perkalian matriks. Dengan menggunakan metode defuzzy winner take all, penggunaan komposisi ini dilakukan sebagai upaya untuk mencegah adanya flat area pada daerah solusi. Pada pengujian ini digunakan input fungsi bukti langsung (a), kehandalan (b) dan ketanggapan (c), untuk output ialah kepuasan pelanggan yang dilakukan penilaian.

Tabel 3.5 Data Pelanggan

\begin{tabular}{|c|c|c|c|c|}
\hline Pengujala & Nama Pelanggan & $\begin{array}{c}\text { Bukti langsung } \\
\text { (a) }\end{array}$ & $\begin{array}{c}\text { Kehandalan } \\
\text { (b) }\end{array}$ & $\begin{array}{c}\text { Ketangaapan } \\
\text { (c) }\end{array}$ \\
\hline 1 & ANI & 80 & 80 & 75 \\
\hline 2 & MIA & 70 & 80 & 70 \\
\hline 3 & ANDRE & 65 & 65 & 70 \\
\hline 5 & TOMI & 60 & 70 & 50 \\
\hline
\end{tabular}

Untuk mendapatkan vektor input A sebelumnya perlu dicari terlebih dahulu derajat keanggotaan nilai tiap variabel dalam setiap himpunan.

$\alpha 1=\mu$ KURANG $[80]=0$

$\alpha 2=\mu C U K U P[80]=0$

$\alpha 3=\mu$ BAGUS $[80]=(80-60 / 20)=1$

$\alpha 4=\mu$ KURANG $[80]=0$

$\alpha 5=\mu C U K U P[80]=0$

$\alpha 6=\mu B A G U S[80]=1$

$\alpha 7=\mu$ KURANG $[75]=0$

$\alpha 8=\mu$ CUKUP $[75]=(80-70) / 10=0.25$

$\alpha 9=\mu$ BAGUS $[75]=(75-60 / 10)=0.75$

Vektor input $A$ :

$\mathrm{A}=(0 ; 0 ; 1 ; 0 ; 0 ; 1: 0 ; 0.25 ; 0.75)$

diperoleh vektor input Ak untuk setiap aturan ke-k $(k=1,2,3, \ldots, 27)$ sebagai berikut:

$\alpha 1=(1,0,0,1,0,0,1,0,0)$;

$\alpha 2=(1,0,0,1,0,0,0,1,0)$;

$\alpha 3=(1,0,0,1,0,0,0,0,1)$;

J-SISKO TECH Vol. 3, No. 1, 2020 : 78-85 


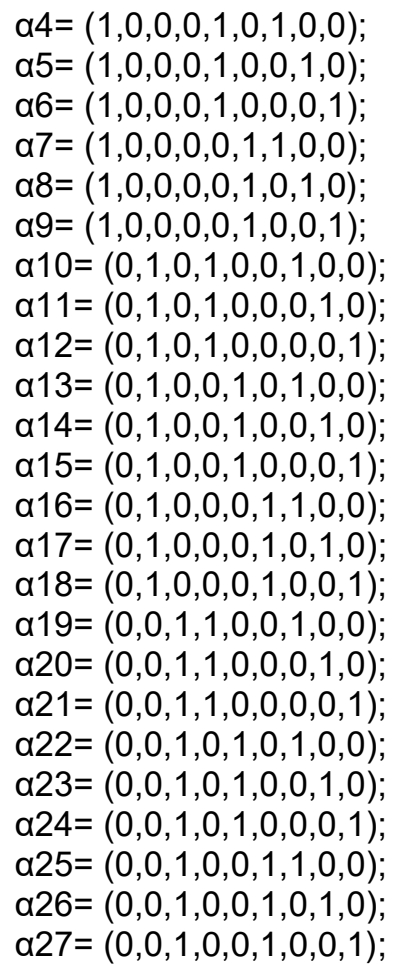

Sedangkan faktor output Bk untuk setiap aturan ke-k $(\mathrm{k}=1,2,3, \ldots, 27)$ adalah sebagai berikut:

$\mathrm{B} 1=(1,0,0,0,0,0,0,0,0,0,0,0,0,0,0,0,0,0,0,0,0,0,0,0,0,0,0)$

$\mathrm{B} 2=(0,1,0,0,0,0,0,0,0,0,0,0,0,0,0,0,0,0,0,0,0,0,0,0,0,0,0)$

B3 $=(0,0,1,0,0,0,0,0,0,0,0,0,0,0,0,0,0,0,0,0,0,0,0,0,0,0,0)$

$\mathrm{B} 4=(0,0,0,1,0,0,0,0,0,0,0,0,0,0,0,0,0,0,0,0,0,0,0,0,0,0,0)$

$\mathrm{B} 5=(0,0,0,0,1,0,0,0,0,0,0,0,0,0,0,0,0,0,0,0,0,0,0,0,0,0,0)$

$\mathrm{B} 6=(0,0,0,0,0,1,0,0,0,0,0,0,0,0,0,0,0,0,0,0,0,0,0,0,0,0,0)$

$\mathrm{B} 7=(0,0,0,0,0,0,1,0,0,0,0,0,0,0,0,0,0,0,0,0,0,0,0,0,0,0,0)$

$\mathrm{B} 8=(0,0,0,0,0,0,0,1,0,0,0,0,0,0,0,0,0,0,0,0,0,0,0,0,0,0,0)$

$\mathrm{B} 9=(0,0,0,0,0,0,0,0,1,0,0,0,0,0,0,0,0,0,0,0,0,0,0,0,0,0,0)$

$\mathrm{B} 10=(0,0,0,0,0,0,0,0,0,1,0,0,0,0,0,0,0,0,0,0,0,0,0,0,0,0,0)$

$\mathrm{B} 11=(0,0,0,0,0,0,0,0,0,0,1,0,0,0,0,0,0,0,0,0,0,0,0,0,0,0,0)$

$B 12=(0,0,0,0,0,0,0,0,0,0,0,1,0,0,0,0,0,0,0,0,0,0,0,0,0,0,0)$

$B 13=(0,0,0,0,0,0,0,0,0,0,0,0,1,0,0,0,0,0,0,0,0,0,0,0,0,0,0)$

$\mathrm{B} 14=(0,0,0,0,0,0,0,0,0,0,0,0,0,1,0,0,0,0,0,0,0,0,0,0,0,0,0)$

$\mathrm{B} 15=(0,0,0,0,0,0,0,0,0,0,0,0,0,0,1,0,0,0,0,0,0,0,0,0,0,0,0)$

$\mathrm{B} 16=(0,0,0,0,0,0,0,0,0,0,0,0,0,0,0,1,0,0,0,0,0,0,0,0,0,0,0)$

$\mathrm{B} 17=(0,0,0,0,0,0,0,0,0,0,0,0,0,0,0,0,1,0,0,0,0,0,0,0,0,0,0)$

$\mathrm{B} 18=(0,0,0,0,0,0,0,0,0,0,0,0,0,0,0,0,0,1,0,0,0,0,0,0,0,0,0)$

$\mathrm{B} 19=(0,0,0,0,0,0,0,0,0,0,0,0,0,0,0,0,0,0,1,0,0,0,0,0,0,0,0)$

$\mathrm{B} 20=(0,0,0,0,0,0,0,0,0,0,0,0,0,0,0,0,0,0,0,1,0,0,0,0,0,0,0)$

$\mathrm{B} 21=(0,0,0,0,0,0,0,0,0,0,0,0,0,0,0,0,0,0,0,0,1,0,0,0,0,0,0)$

$\mathrm{B} 22=(0,0,0,0,0,0,0,0,0,0,0,0,0,0,0,0,0,0,0,0,0,1,0,0,0,0,0)$

B23 $=(0,0,0,0,0,0,0,0,0,0,0,0,0,0,0,0,0,0,0,0,0,0,1,0,0,0,0)$

$\mathrm{B} 24=(0,0,0,0,0,0,0,0,0,0,0,0,0,0,0,0,0,0,0,0,0,0,0,1,0,0,0)$

B25 $=(0,0,0,0,0,0,0,0,0,0,0,0,0,0,0,0,0,0,0,0,0,0,0,0,1,0,0)$ 
$\mathrm{B} 26=(0,0,0,0,0,0,0,0,0,0,0,0,0,0,0,0,0,0,0,0,0,0,0,0,0,1,0)$

$\mathrm{B} 27=(0,0,0,0,0,0,0,0,0,0,0,0,0,0,0,0,0,0,0,0,0,0,0,0,0,0,1)$

Kemudian diperoleh nilai 27 matriks FAM (M1,M2,M3,..,M27) :

Setelah diperoleh nilai Bk', akan didapat nilai vektor B dari penjumlahan Bk' yaitu:

$\mathrm{B}=$

$\begin{array}{llllllllll}0 & & 0,25 & 0,75 & 0 & 0,25 & 0,75 & 1 & 1,25 & 1,75 \\ 0 & & 0,25 & 0,75 & 0 & 0,25 & 0,75 & 1 & 1,25 & 1,75 \\ & 1 & 1,75 & 1,75 & 1 & 1,25 & 1,75 & 2 & 2,25 & 2,75\end{array}$

5. Deffuzyfikasi

Pada pengujian Indomaret 1 elemen terbesar dari vektor B adalah elemen ke-27 $(=2,75)$, dengan menggunakan metode defuzzy winner take all diperoleh nilai y yang merupakan output, yaitu Sangat memuaskan.

\begin{tabular}{|c|c|c|c|}
\hline $\begin{array}{c}\text { Nama } \\
\text { Pelanggan }\end{array}$ & Elemen ke- & Nilai & Hasil \\
\hline ANI & 27 & 2,75 & Sangat Memuaskan \\
\hline MIA & 27 & 2.5 & Sangat Memuaskan \\
\hline ANDRE & 15 & 2.25 & Cukup \\
\hline TOMI & 14,17 & 2,5 & Cukup \\
\hline DINA & 1,4 & 2,5 & $\begin{array}{c}\text { Kurang } \\
\text { Memuaskan }\end{array}$ \\
\hline
\end{tabular}

Setelah melakukan proses implementasi, proses selanjutnya adalah melakukan pengujian terhadap sistem yang telah dibangun. Pengujian ini untuk melihat bahwa hasil perancangan dan perhitungan yang ada di bab III sesuai dengan hasil yang di tampilkan pada sistem. Keluaran yang dihasilkan oleh sistem akan disesuaikan dengan hasil perhitungan

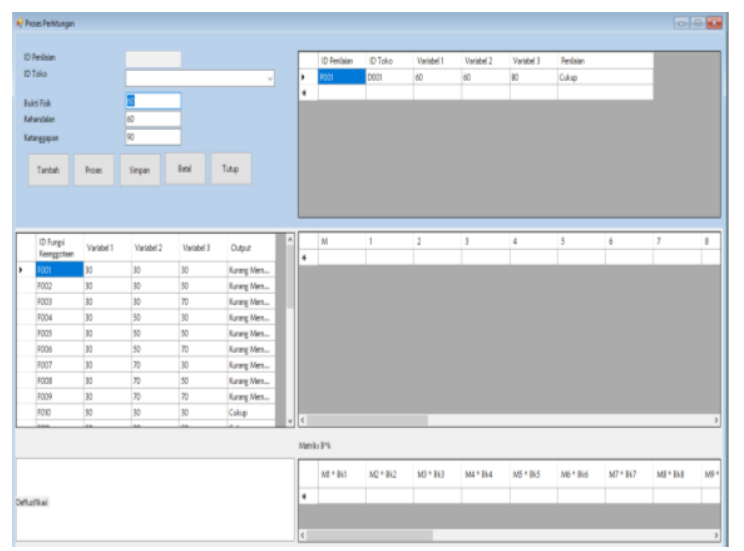

Gambar 3 Hasil FAM

\section{Kesimpulan}

Berdasarkan analisa pada permasalahan yang terjadi dalam kasus yang diangkat tentang penilaian kepuasan pelanggan terhadap pelayanan di toko indomaret dengan menggunakan metode Fuzzy Associative Memory, maka dapat ditarik kesimpulan sebagai berikut :

J-SISKO TECH Vol. 3, No. 1, $2020: 78-85$ 
1. Dengan menggunakan metode Fuzzy Associative Memorydapat membantu menentukan tingkat kepuasan pelanggan di toko indomaret.

2. Dengan adanya sistem pendukung keputusan sedikitnya dapat membantuuntuk perbaikan tampilan/bukti langsung (tangibles), keandalan karyawan (reliability) dan kesigapan karyawan (responsiveness) guna memenuhi kepuasan pelanggan, sehingga dapat menentukan langkah-langkah selanjutnya yang diambil dalam mengukur kebijaksanaan dimasa yang akan datang.

3. Pembangunan sistem pendukung keputusan menggunakan metode Fuzzy Associative Memory dapat dilakukan melalui pengkodean menggunakan bahasa pemograman berbasis Desktop Programming sehingga dapat menjadi solusi menentukan tingkat kepuasan pelanggan.

\section{DAFTAR PUSTAKA}

Al-Bahra bin Ladjamudin. 2005. Analisis dan desain sistem informasi (edisi pertama).

Yogyakarta : Graha IImu.

Hendrayudi. 2011. Dasar-Dasar Pemrograman Visual Basic 2008. Bandung : Sarana Tutorial Nurani Sejahtera.

Kusrini. 2017. Konsep dan Aplikasi Sistem Pendukung Keputusan. Yogyakarta :ANDI.

Kusumadewi, S. \& Purnomo, H. 2013. Aplikasi Logika Fuzzy untuk Pendukung Keputusan.(Cetakan Kedua).Yogyakarta : Graha Ilmu.

Latif, F. \& Pratama, A.W. 2015. Perancangan Sistm Informasi Manajemen Arsip Elektronik ( EArsip) Berbasis Mirosoft Acces pada PT. Hi-Test. Jurnal akuntansi, Ekonomi dan Manajemen Bisnis, 3(1), 21-31.

Pratiwi, H. 2016. Buku Ajar Pendukung Keputusan.Yogyakarta : Deepublish.

Ramenusa, O. 2013. Kualitas Layanan dan Kepuasan Pelanggan Pengaruhnya terhadap Loyalitas Pelanggan pada PT.DGS Manado. Jurnal EMBA 1(3).1193-1202.

Rosa, A. S., \& Shalahuddin, M. 2015. Rekayasa Perangkat Lunak Terstruktur dan Berorientasi Objek. Bandung : Informatika J. Breckling, Ed., The Analysis of Directional Time Series: Applications to Wind Speed and Direction, ser. Lecture Notes in Statistics. Berlin, Germany: Springer, 1989, vol. 61. 